\title{
Correction to: Clinical symptoms of androgen deficiency in men with migraine or cluster headache: a cross-sectional cohort study
}

Iris E. Verhagen ${ }^{1,2+}$, Roemer B. Brandt ${ }^{1 \dagger}$, Carlijn M. A. Kruitbosch', Antoinette MaassenVanDenBrink², Rolf Fronczek ${ }^{1 \dagger}$ and Gisela M. Terwindt ${ }^{1 *+}$

Correction to: J Headache Pain 22, 125 (2021) http://orcid.org/10.1186/s10194-021-01334-3

Following the publication of the original article [1], we were notified of a few corrections:

1. The corresponding author should be Gisela M. Terwindt, instead of Iris E. Verhagen.

2. In the Results section of the Abstract, the phrase "Responders were older compared to nonresponders and more likely to suffer from lifetime depression" should read "Responders were older compared to non-responders and less likely to suffer from lifetime depression".

3. ICHD-II and ICHD-III were modified into ICHD-2 and ICHD-3.

The original article has been corrected.

\section{Author details}

'Department of Neurology, Leiden University Medical Center, P.O. 9600, 2300 Leiden, WB, The Netherlands. ${ }^{2}$ Department of Internal Medicine, Erasmus University Medical Center, Rotterdam, The Netherlands.
Published online: 09 November 2021

\section{Reference}

1. Verhagen IE et al (2021) Clinical symptoms of androgen deficiency in men with migraine or cluster headache: a cross-sectional cohort study. J Headache Pain 22:125. https://doi.org/10.1186/s10194-021-01334-3

The original article can be found online at https://doi.org/10.1186/s10194021-01334-3.

* Correspondence: G.M.Terwindt@lumc.nl

†'ris E. Verhagen, Roemer B. Brandt, Rolf Fronczek and Gisela M. Terwindt contributed equally to this work.

'Department of Neurology, Leiden University Medical Center, P.O. 9600, 2300 Leiden, WB, The Netherlands

C C The Author(s). 2021 Open Access This article is licensed under a Creative Commons Attribution 4.0 International License, which permits use, sharing, adaptation, distribution and reproduction in any medium or format, as long as you give appropriate credit to the original author(s) and the source, provide a link to the Creative Commons licence, and indicate if changes were made. The images or other third party material in this article are included in the article's Creative Commons licence, unless indicated otherwise in a credit line to the material. If material is not included in the article's Creative Commons licence and your intended use is not permitted by statutory regulation or exceeds the permitted use, you will need to obtain permission directly from the copyright holder. To view a copy of this licence, visit http://creativecommons.org/licenses/by/4.0/. The Creative Commons Public Domain Dedication waiver (http://creativecommons.org/publicdomain/zero/1.0/) applies to the data made available in this article, unless otherwise stated in a credit line to the data. 